\title{
Why Wine Tourists Visit Cellar Doors: Segmenting Motivation and Destination Image
}

\author{
Bruwer, $\mathrm{J}^{\mathrm{a}, *}$, Prayag, $\mathrm{G}^{\mathrm{b}}$, Disegna, $\mathrm{M}^{\mathrm{c}}$
}

${ }^{a}$ Ehrenberg-Bass Institute for Marketing Science, University of South Australia, Adelaide, Australia

${ }^{b} U C$ Business School, University of Canterbury, Christchurch, New Zealand

${ }^{c}$ Faculty of Management, Executive Business Centre, Bournemouth University, Bournemouth, United Kingdom

\begin{abstract}
This study examines the relationship between the motivation of wine tourists to visit cellar doors and destination image perception. A survey of tourists resulted in 676 useable questionnaires. Using a novel segmentation method, self-organizing maps (SOM) and bagged clustering (BC), the study identified five distinct motivation clusters. These clusters were different on only gender and previous visit to the wine region. Three clusters of destination image were identified using the same segmentation method. Significant relationships were found between the motivation and destination image clusters. Implications for destination marketing and managing the tourist experience at the winery cellar door are discussed.
\end{abstract}

Keywords: Wine tourists, segmentation, self-organizing maps, bagged clustering, cellar door, Barossa Valley

*Corresponding author Email addresses: johan.bruwer@unisa.edu.au (Bruwer Johan); girish.prayag@canterbury.ac.nz (Girish Prayag); disegnam@bournemouth.ac.uk (Marta Disegna) 


\section{INTRODUCTION}

The wine tourist is someone who feels a need to 'connect' with the origin of the product through visitation of the location (wine region) where wine is produced. Wine tourism research has brought some salient factors and differences to light based on socio-demographics (Charters \& Ali-Knight, 2002; Getz \& Brown, 2006), destination analysis (Bruwer, Gross \& Lee, 2016), and travel motivation (Getz \& Brown, 2006). While many segmentation studies exist of different types of tourists using different methodologies, existing research segmenting the wine tourism experience remains rather scant.

The use of motivation as a basis for segmenting tourist markets has however, provided insight into why consumers desire to visit wine destinations and regions (Alebaki \& Iakovidou, 2011). Moreover, understanding wine tourists' motives and preferences for activities represents a promising direction in linking visitors' needs to the attributes of the destination (Pearce \& Lee, 2005). A popular view is that tourist motivation centres around the concept of 'push' and 'pull' factors which impact on destination choice (Prayag \& Ryan, 2011). This suggests that tourists are pushed by their own motivational strengths and 'pulled' by a destination's attractions (Chen \& Chen, 2015). The push-pull motivation framework has been used extensively for studying why tourists travel (Chen \& Chen, 2015; Li, Meng, Uysal, \& Mihalik 2013; Prayag \& Hosany, 2014), but few have applied the framework to understand tourists at cellar doors (Sparks, 2007; Yuan, Cai, Morrison, \& Linton, 2005), and their perceptions of destination image.

The importance and influence of destination pull attributes on destination choice may differ considerably for different market segments (Albayrak \& Caber, 2013). For example, the relative importance of pull attributes has been found to differ for visitors of different sociodemographic characteristics (Kim, Lee \& Klenosky, 2003; Prayag, 2010). Other studies have identified factors, such as learning about wine, interest in wine regions, relaxation, exploration, socialization, and involvement with wine as important motivational factors in wine tourism. Whether motivations are studied from the push-pull theoretical basis or from a purely psychological perspective, this alludes to interrelated activities within the overall wine tourism experience (Cho, Bonn \& Brymer, 2017). Our research thus adopted the premise that visit motivation (push) and destination image (pull) are interrelated and can be used for segmentation purposes as suggested in previous studies (Baloglu \& Uysal, 1996; Prayag \& Hosany, 2014). More specifically, our study contributes to the segmentation literature by 
introducing an 'ensemble' method, which is a combination of two existing segmentation methods. Specifically, Self-Organizing Maps (SOM), which is one of the most important Neural Networks (NNs) algorithms along with Bagged Clustering (BC), are used to understand the relationship between motivation of tourists and wine destination attributes. This new ensemble method introduces a post hoc segmentation approach to the tourism literature, which offers a more sophisticated profile of wine tourist segments and how they respond at the wine regional destination.

\section{LITERATURE REVIEW}

\subsection{Tourist experience at cellar doors}

Andersson (2007, p.46) describes the tourist experience as "the moment when tourism consumption and tourism production meet." The nexus of what has become known as the 'experience economy' (Pine and Gilmore, 1998) is that tourists seek unique and memorable experiences such as authenticity, silent relaxation and 'soft' tourism experiences such as oceancruising, or wine tourism (Pikkemaat, Peters, Boksberger \& Secco, 2009). The emergent trend for tourism providers to focus on providing a memorable, often staged experience, has prompted some tourism researchers to employ customer experience or hedonic consumption theories (Hirschman \& Holbrook, 1982; Knutson, Beck, Kim \& Cha, 2007). Although there is no single theory that defines tourist experience, the hedonic view of tourism consumption underlines the relevance of its theoretical framework to understanding the experiences sought by tourists. This prompted Quadri-Felitti and Fiore $(2012$, p.5) to conclude that this "affords a logical connection to wine tourism with its emphasis on senses, emotions, and enjoyment of pastoral settings." Few wine tourism studies have focused on the total experience aspect, in other words, what reasons other than the obvious "to taste" and "buy wine" actually motivated them to visit (Asero \& Patti, 2011; Chen, Goodman, Bruwer \& Cohen, 2016).

The winery cellar door is the hub of the visitor's wine tourism experience (Bruwer, Coode, Saliba \& Herbst, 2013) presenting winery owners with the opportunity to provide an authentic and memorable experience. It increases visitors' awareness of the winery brand, develops their knowledge and understanding of the wine region destination, and impacts upon post-visit buying behaviour (Bruwer, Lesschaeve \& Campbell, 2012). The total tourism experience occurs in the context of what is known as the winescape (Quintal, Thomas \& Phau, 2015) and 
could have an impact on the perception thereof as per our argument in a subsequent sub-section on destination image.

\subsection{Motivations of Wine Tourists}

Motivation researchers have conceptualised several theories and models to explain motivation (i.e. Dann, 1977; Hsu, Cai \& Li, 2010), but still these only partially meet all the requirements of a good theory (Pearce \& Lee, 2005). Among the theoretical frameworks and models emanating during the evolvement process when researchers attempted to explain human motivation, the push-pull theory originally introduced by Dann (1977), is arguably the best-known and, is by now, commonly adopted in destination marketing research (Kim, Holland \& Han, 2013). The general appeal found by push-pull motivation theory among tourism researchers has been attributed to its intuitive approach (Klenosky, 2002) and simplicity (Mohsin \& Alsawafi, 2011). The push-pull framework has been used extensively for studying why tourists travel (Chen \& Chen, 2015; Li et al., 2013; Prayag \& Hosany, 2014). Push factors motivate individuals to travel away from home, and pull factors draw them towards specific destinations (Prayag \& Ryan, 2011). Pull factors are travel destination-specific factors that influence destination choice (Klenosky, 2002). Pull factors are also considered as attributes that form destination image in the visitors' minds on the basis of their expectations and perceptions of the destination (Li et al., 2013; Prayag \& Ryan, 2011).

The intense social context of wine tourism behaviour has been confirmed in studies showing that people who engage in this activity, are almost always accompanied by others (Bruwer and Alant, 2009). Researchers have also confirmed that the primary motivations of wine tourists are to "taste" and "buy wine" (Alant \& Bruwer, 2004; Charters \& Ali-Knight, 2002). Hence, we propose that wine tourism lends itself to further exploration of the motivations that drive tourists to consumption, and that this is also reflected in their perception of the destination's imagery or winescape, particularly when examined from an experiential viewpoint (i.e. Bruwer \& Alant, 2009).

Because of the rural setting in which wine tourism occurs, it is plausible that environmental arousal could be at the root of the motives of wine tourists to satisfy their needs. It should also be kept in mind that not all wine tourists are necessarily wine drinkers and therefore have winerelated motivations (Douglas, Douglas \& Derrett, 2001). Other than to taste and buy wine, there are also 'secondary' motivations such as learning about wine, socialising, being entertained, 
travelling in a rural setting, relaxation, and so forth that round off the experience (Getz \& Brown, 2006).

A gap exists in the knowledge base in that little is known about the motivational forces that drive wine tourists to consumption (Ravenscroft \& van Westering, 2001). According to Nicolau and Mas (2006) most studies assume independence between tourist motivations and attributes of the tourism destination. This is also our approach in this study and hence we attempt to explain the decisions through interaction of wine regional characteristics with the personal motivations of the tourist. In the process we enrich the knowledge base by being the first study in wine tourism to link destination attributes to visit motivations using a novel selforganizing maps (SOM) and bagged clustering (BC) segmentation approach.

\subsection{Destination image and wine tourism}

Tourism destination image (TDI) perception plays an important role in the tourism destination visit decision, whether this decision is primarily driven by motivation to have a holiday, participate in recreational activity, visit friends and/or relatives, and in the case of wine tourism, taste and/or buy wine (Bruwer \& Joy, 2017). Not surprisingly, TDI has been the focus of much research and different methodological approaches to understand this tourism construct exist (i.e. Quintal et al., 2015; Stepchenkova \& Mills, 2010). In this context, wine tourism has emerged as a special-interest tourism field from an academic research perspective. During this process the inclusion of wine as a TDI element received some coverage in the literature (i.e. Bruwer et al., 2016; Getz \& Brown, 2006; Quintal et al., 2015). This coincided with visitation to wineries to experience winemaking, grapegrowing and wine consumption becoming popular tourist activities (Marzo-Navarro \& Pedraja-Iglesias, 2012).

The push-pull theory of motivation discussed earlier, is conceptually related to the characteristics of the tourist destination, more specifically the 'winescape', when attempting to develop a better understanding of the consumption of wine tourism and why tourists select a specific regional destination. This is a central tenet of the segmentation approach we develop in the current study. Dann (1977) identified two key push motivation forces, namely, the desire to escape, or to seek out novel experiences. On the other hand, pull motivation factors encompass tourist destination attributes that play an important role in the destination decision process (Correia \& Pimpão, 2008). Pull motivations therefore relate to the attractiveness of tourist destinations and encompass tangible resources that destinations possess and tourists' 
perceptions and expectations of these (Mohsin \& Alsawafi, 2011). In the current study, it is proposed that regional destination's attributes, such as its wine quality, setting, and service staff pull wine tourists to experience the destination, also known as the 'winescape'.

Two main approaches exist in conceptualising the winescape. The first, a macro approach, defines the winescape in general terms, by referring to it as "the whole region and its attributes" (Alebaki and Lakovidou, 2011, p.123) and, "physical, social and cultural dimensions...and its components" (Douglas et al., 2001, p.313). The second approach defines the winescape in specific terms by identifying three main elements: the presence of vineyards, winemaking activity, and winery facilities where wine is produced and stored (Bruwer et al., 2016).

\subsection{Segmentation research on wine tourists}

A useful precis of the evolvement and current state of market segmentation in wine tourism is provided by Molina, Gómez, González-Díaz and Esteban (2015). From this we conclude that much of the published segmentation research on wine tourists is not directly tourism-related, but instead mostly focused on their wine consumption habits and other wine consumer-related behavioural aspects. For example, although motivational attributes have been examined in wine segmentation studies (i.e. Alebaki and Iakovidou, 2011; Mitchell \& Hall, 2006), this research area has not been fully developed (Bruwer et al., 2013). Looking back over 30 years of wine tourism research, the ad hoc nature of research on market segmentation of wine tourists is evident. Alebaki and Iakovidou (2011, p.125) attempt to provide more 'structure' to the process of market segmentation of wine tourists by suggesting that researchers consider: if wine tourists are a distinct group with specific characteristics compared to an average traveller in rural areas or urban centers, and whether wine constitutes the main reason for visiting a wine region.

There is evidence to confirm that visitors to wineries have different profiles. Through their meta-analysis of wine tourism segmentation research Molina et al. (2015) conclude that in general, two procedures can be used to segment wine tourists: classifying visitors by considering their demographic factors and, establishing a profile by detailing their psychographic characteristics (i.e. attitudes, lifestyle). Romano and Natilli (2009) present a segmentation structure based on demographic variables and added other variables, such as preferences when buying food, interest in gastronomic media, and level of technological knowledge. 
A number of studies have sought to identify wine tourists by generating psychographic (lifestyle) segmentation structures (Mitchell \& Hall, 2006), and by measuring their involvement or attachment to wine and destinations (Nella \& Christou, 2014). These constructs have also been linked to hedonic and experiential consumption (Bruwer \& Alant, 2009). Visitor motivation research reveals that wine tourists also seek shopping, dining, and cultural and recreational outlets (Bruwer et al., 2012; Getz \& Brown, 2006). Clearly wine tourists want more from their wine tourism destination experience than just to taste and buy wines.

\section{METHOD}

Existing segmentation studies on tourists to wineries and wine festivals (i.e. Chen \& Sasias, 2014; Cho at al., 2017; Nella \& Christou, 2014) continue to use the much-criticized factor-cluster analysis (Dolnicar \& Grün, 2008) to derive segments. This approach to segmentation casts doubt on the stability and reproducibility of the identified clusters. With the exception of a few studies (i.e. Molina et al., 2015) that use latent class analysis (LCA), robust segmentation methods such as (Bloom, 2004, 2005; Li, Law \& Wang, 2010; Mazanec, 1994) and ensemble methods among which bagged clustering (Dolnicar \& Leisch, 2003; Prayag, Disegna, Cohen \& Yan, 2015, D’Urso, Disegna, Massari \& Prayag, 2015), are sparsely used in tourism studies. In particular, ensemble methods refer to a set of individually trained classifiers (such as neural networks and clustering methods) whose findings are combined to generate clusters (Opitz \& Maclin, 1999). Ensemble methods are often more accurate than any single classification method in segmenting markets (Opitz \& Maclin, 1999). Accordingly, this study uses a novel ensemble method, Self-Organizing Maps (SOM) and bagged clustering (BC), to derive stable segments.

\subsection{Survey instrument}

This study was part of a larger project on wine tourism experiences at the cellar door, but focuses on the project's motivation and destination image aspects only. The data collection instrument was a purpose-designed highly-structured questionnaire which comprised several sections. Motivation was measured using 15 items from which visitors had to rank those that apply to them on an importance scale ranging from most important $(=1)$ to the least important one (rating number dependent on the number of motivations applicable). The items were adopted from previous wine tourism studies (Bruwer et al., 2012). Destination image was measured using 24 items that employed a free-text macro approach similar to that used by Bruwer et al. (2016) 
and Bruwer and Gross (2017). Several socio-demographic and wine consumption-related questions were also measured (see Table 3). The questionnaire was pre-tested on tourists at the winery cellar door.

\subsection{Sampling and data collection}

The sampling frame was 17 winery cellar doors within the Barossa Valley Wine Region in South Australia. Barossa is Australia's premier wine region and located only a 1-hour drive from the Adelaide CBD, South Australia's capital city. The cellar doors were chosen to reflect a broad range of cellar door sizes to obtain a wide as possible range of visitors and have an acceptable degree of fit with the universum of 70 cellar doors. A time-based random sampling design was used, with no quotas imposed relating to any characteristic of the visitors.

The research questionnaires were administered at the cellar doors where data collection took place during a 6-8 week period in 2015. Cellar door staff were given clear instructions on ensuring randomness when recruiting visitors to participate in the survey. For example, only one respondent from a household could participate in the survey and a time-based systematic random sampling technique used, first identifying visitors randomly as they arrived during different times of the day and days of the week, but waiting until the identified persons were ready to depart. This ensured that visitors had first enjoyed the wine tourism experience before participating in the research. The self-administered surveys were completed in situ at the cellar doors, ensuring that information pertaining to the visit experience was still fresh in the minds of the respondents. Incentives were offered in the form of entry in a lucky draw for a case of the region's best wine. A total of 814 questionnaires were collected, however, the final number of usable questionnaires is 676 due to excessive missing information in 138 questionnaires which were subsequently discarded.

\subsection{Data analysis}

Market segmentation usually consists of three phases. In the first phase, the researcher selects and, if necessary, transforms the segmentation variables. In phase two, the researcher adopts a suitable segmentation technique and in the last stage, the clusters are profiled. In this study, the motivation items were used as the segmentation variables. Figure 1 schematically describes phases two and three of the segmentation procedure. The two-level approach of SOM, namely SOM-BC method (see Figure 1) adopted in this study has the purpose of finding both micro (i.e. output nodes) and macro (i.e. aggregation of output nodes) segments of tourists. 
Kohonen Maps (Kohonen, 1984), also known as Self-Organizing Maps (SOM), is an unsupervised artificial neural network that has the capacity to map the observed points (input data) from a $n$-dimensional input layer (or space) to a lower dimensional output layer (i.e. the Kohonen layer) while maintaining the original topological relationships, meaning the order of the interrelationships among the units are preserved. The results of SOM are usually represented through two types of graphs, the $U$-matrix and the component plane, i.e. a set of $U$-matrices each of which represents a segmentation variable. The $U$-matrix is built on the basis of the distance matrix calculated between neighbourhood output nodes. SOM as a segmentation technique is more robust and stable compared to traditional clustering techniques (Kohonen, 1995; Venugopal \& Baets, 1994). The batch version of the SOM algorithm has been used to arrange the nodes in a hexagonal grid (see Figure 2). This version of SOM was chosen because it is computationally faster, does not require the specification of a learning rate (Kohonen, 1998), and allows to obtain higher performance compared to the more traditional sequential SOM algorithm (Vesanto \& Alboniemi, 2000). The initial values of the weight vector were chosen using a linear initialization procedure and the number of nodes in the output layer is $M=5 \sqrt{N}$ (Sang, Gelfand, Lennard, Hegerl \& Hewitson, 2008) resulting in a $13 \times 10$ SOM. A more detailed overview of this approach is provided in other studies (Brida et al., 2012; Li et al., 2010).

Next, the SOM findings are clustered again by means of the BC algorithm in which the $k$ means is used as the partitioning method, with $K=20$ centers and 10,000 iterations used as the base method. The bagging ("bootstrap aggregating") procedure has been extensively described in previous studies (see Prayag et al., 2015). A number of bootstrap samples $(B=1,000)$ were considered, resulting in a total of 20,000 centers, which were then hierarchically clustered using Euclidean distance and Ward's agglomerative linkage method. These parameters were chosen as they have provided the best performances in previous studies (Dolnicar \& Leisch, 2004). In the final stage of the segmentation procedure, the motivation clusters were profiled by means of multinomial logistic regressions using the destination image items and behaviours at the cellar doors, as well as several socio-demographic tourist characteristics, as explanatory variables.

[Take Figure 1 in here]

\section{RESULTS}




\subsection{Socio-Demographic characteristics of sample}

The demographic profile of the sample showed a majority of males $(52.7 \%)$ as tourists at the cellar doors. Different age groups were captured: 18 to 28 years old (21.5\%), 29 to 40 years old (30.9\%), 41 to 54 years old (28.3\%), and 55 years old and above (19.4\%). Of the respondents, $21.1 \%$ had completed secondary school, $17.2 \%$ had completed a TAFE certificate or diploma, and $29.5 \%$ had completed a Bachelor's degree. The remaining $32.2 \%$ of respondents had completed postgraduate studies. The sample earned AU\$ 50,000 and less as their annual household income $(13.3 \%)$ with the majority $(50.5 \%)$ earning more than AU\$ 100,000 a year. In total, $84.2 \%$ were domestic visitors with the majority of international visitors coming from the UK (29\%), the USA (25.2\%), Germany (11.2\%), and New Zealand (9.3\%). The sample had slightly more repeating $(51.7 \%)$ visitors to the Barossa region. A more detailed overview of the sample characteristics is provided in Table 3.

\subsection{Motivation clusters using SOM and BC}

In the $U$-matrix (Figure 2), the red colour represents a large distance between neighbouring neurons and, therefore, indicates cluster borders, while the blue colour represents neighbouring neurons with similar characteristics. The number of input units grouped in each output node (or microsegment) is reported when this value is greater than 9. From Figure 2, it is difficult to identify macrosegments, which have similar characteristics given that the borders of these potential groups are not clearly identified. Hence, the choice to adopt the two-level approach (Figure 1) and to process the weight vectors with another clustering technique to identify clearly discernible clusters.

[Take Figure 2 in here]

In Figure 3, the results of the BC algorithm are shown, with the upper part of the figure (the dendrogram) showing aggregation distances of each of the clusters. The lower part reports the standardized absolute heights (black line) while the grey line denotes first differences. 'Sudden bends' of the black line and/or local peaks of the grey one drive the selection of the final number of clusters (Everitt, Landau, Leese \& Stahl, 2011). The results suggest that respondents can be segmented in either two or five clusters. Given that the purpose of the analysis is also to identify micro-segments of tourists, the five-cluster solution is interpreted. 
[Take Figure 3 in here]

As shown in Table 1, cluster three (CL3) is the largest (49\%) while cluster four (CL4) is the smallest (4\%). Cluster one (CL1) ranked the motive of tasting wine (52\%) as the most important for visiting the cellar door followed by atmosphere, buy wine and day out (21\%) ranked as the second most important motives. This cluster was also driven by the motive of learning about wine (23\%), ranked third and fourth most important, and thus was labelled as "Wine Learners". Cluster two (CL2) ranked the motive of eating at the winery $(25 \%)$ as the most important followed by experiencing the atmosphere (13\%) in second and third positions. This cluster ranked the visit to a rural setting as the fourth most important motive and, thus, was labelled as "Dining Enthusiasts". CL3 was driven mainly by motives of tasting (61\%) and buying wine (26\%) ranked as second, third and fourth most important and thus was labelled "Wine Buyers". While CL4 was also largely driven by tasting wine (33\%) as the most important motive, this cluster assigned high importance to the motive of learning about wine (19\%), ranked as the third most important, and the day out (19\%) as the fourth most important motive for visiting the cellar door. This cluster was thus labelled "Wine Enthusiasts". Cluster five (CL5) also ranked the motive of tasting wine as the most important (47\%) and this motive featured more prominently in this cluster compared to all other clusters. This cluster was also motivated by the need to buy wine as shown by the ranking of fourth and fifth in terms of importance levels (16\% and 12\% respectively), while the motive of finding a unique wine was ranked fifth (12\%). As such, this cluster was labelled "Wine Connoisseurs".

[Take Table 1 in here]

\subsection{Destination image clusters using SOM and BC}

The same procedure described in Figure 1 was applied to the destination image attributes to cluster respondents. The best partitioning solution was represented by three clusters as shown in Table 2. ANOVA with post-hoc tests (Tukey's pairwise comparisons) was used to identify similarities and differences between the clusters in image perceptions. The results showed significant differences on 12 of the 24 items. 
The results indicate that a higher proportion of respondents in cluster $2(76.8 \%)$ in comparison to cluster $3(63.2 \%)$ associated local food/cuisine with the Barossa region, while cluster 1 does not differ significantly from either cluster 2 or cluster 3 regarding this particular attribute. On the attribute of quality of restaurants/pubs, cluster $1(94 \%)$ had a higher proportion of respondents that associated this attribute with the region compared to cluster $2(84.6 \%)$ but does not differ significantly from cluster 3. Cluster 3 by far had the highest proportion of respondents $(82.5 \%)$ that associated availability of tourist information with the region compared to both cluster $1(55.5 \%)$ and cluster $2(56.6 \%)$. Though only $30.3 \%$ of the whole sample associated the attribute value-for-money with the region, there was a statistically significant difference between cluster $2(27.7 \%)$ and cluster $3(40.4 \%)$. In contrast to cluster 1 , cluster 2 contains the majority of people $(3.36 \%)$ that associate friendly residents with the region. Overall, local food/cuisine (73.2\%), quality of restaurants/pubs (88.7\%), availability of tourist information $(60.7 \%)$ and scenery/natural environment $(59.3 \%)$ are the attributes associated the most with the region by tourists that characterised the clusters.

[Take Table 2 in here]

\subsection{Cluster profiling by image, behaviours and socio-demographic characteristics}

Table 3 shows the results of profiling the motivation clusters by destination image clusters, wine and cellar door related behaviours, and socio-demographic characteristics. The motivation clusters were statistically different on their visitation status to the wine region. A higher proportion of respondents that were repeat visitors to the region $(54.7 \%)$ belongs to CL5 compared to CL1 (31.3\%) and CL4 (40.7\%). In terms of socio-demographic characteristics, a higher proportion of males $69.5 \%$ belong to CL2 in comparison to CL3 (43.7\%), CL4 (48.2\%), and CL5 (53.1\%). On all the other socio-demographic characteristics, the motivation clusters were not different.

[Take Table 3 in here]

\subsection{Predicting cluster membership}


The results were further analysed using a multinomial logit model to predict motivation cluster membership on the basis of destination image clusters, wine-related behaviours, and sociodemographic characteristics. The model was configured using CL4 as the baseline group given that it was the smallest cluster. Table 4 shows that in comparison to CL4, all other motivation clusters are different on the basis of the destination image clusters. For example, 'Wine Connoisseurs' were less likely to belong to this cluster when compared to 'Wine Enthusiasts' if they associated the Barossa region with images such as "local food/cuisine", "friendly residents", "shopping facilities" and "cleanliness" (Destination image - CL2). Respondents were less likely to belong to the 'Dining Enthusiasts' cluster in comparison to the 'Wine Enthusiasts', if they associated images of "availability of tourist information", "value-formoney" and "other local products" with the region (Destination image - CL3).

[Take Table 4 in here]

Similarly, Table 4 shows that males and tourists who spend more money at the cellar door are more likely to belong to the cluster of 'Dining Enthusiasts' rather than 'Wine Enthusiasts'. Tourists of European origin are less likely to belong to the cluster of 'Wine Connoisseurs' in comparison to 'Wine Enthusiasts'. Tourists with an annual household income of between AU\$ 50,000 to $\$ 75,000$ and those earning $\$ 100,000$ or more tend to belong to 'Wine Learners' rather than 'Wine Enthusiasts'.

\section{CONCLUSIONS, IMPLICATIONS AND FUTURE RESEARCH}

The objective of the study is to identify any relationship between motivation and destination image of tourists at cellar doors. The results suggest the existence of five motivation clusters and three destination image clusters with some relationships between the two sets of clusters as well as socio-demographic characteristics. From a theoretical perspective, the results suggest that tourists at cellar doors are not homogeneous in both their push and pull factors of visitation. In line with other wine tourism studies (Alant \& Bruwer, 2004; Charters \& AliKnight, 2002), we confirm that tasting and buying wine are the primary motives for visitation. However, the findings also suggest that hedonic motivations associated with the atmosphere, dining, and learning about wine at the cellar door are more significant motives of visitation for some tourists (Wine Learners and Dining Enthusiasts) than others (Bruwer \& Alant, 2009). 
Therefore, not all tourists can be treated as wine drinkers since they don't have wine-related motivations (Douglas et al., 2001).

This has managerial implications for how wineries market the cellar door experience aspect of wine tourism. The importance of the hedonic side of the experiential aspect of wine tourism is highlighted in that hedonically-based motivations are strong drivers towards visitation (Bruwer \& Alant, 2009). Aspects such as tasting wine, eating at the winery, and enjoying the relaxing setting should be regarded by wine tourism providers as of paramount importance and hence developed and utilised to the fullest extent possible. The findings also confirm the importance of atmospherics and learning in marketing the experiential aspects of the cellar door experience. As such, the role of the winescape (Bruwer and Gross, 2017; Quintal et al., 2015) is highlighted and must be managed to meet the expectations of different segments. While some aspects, for example the scenery, is beyond the control of the providers it should be showcased to the maximum extent through smart building design, outdoor patios for summer time, etc. Several experiential aspects are however, well within the control of the providers. For example, staff should be professionally trained and made to understand what the needs of visitors are likely to be, i.e. there can be no 'excuse' for lack of knowledge about the winery, the region, its history, and so on as visitors are likely to want thus type of information. The findings highlight that buying wine is not necessarily an important motive for some wine tourists (Wine Enthusiasts) suggesting that an overemphasis on merchandising by wineries may be counter-productive for some segments.

By applying the push-pull motivation framework to segment tourists at the cellar door, the findings confirm the interrelationships between the two factors suggested in previous studies (Baloglu \& Usyal, 1996; Li et al., 2013; Prayag \& Hosany, 2014). Specifically, in the case of the Barossa region, the destination attributes are not homogeneous in pulling visitors to the region. Some visitors (destination image - CL2) are more sensitive to the local food/cuisine of the region while others (destination image - CL1) are more sensitive to the quality of restaurants/pubs in the region. These findings highlight the need for wineries to understand the experience of the tourist beyond the cellar door and how the cellar door experience fits within the larger regional tourist experience. Such an understanding can improve the marketing of wineries within the region but also contribute to more precise targeting strategies for different segments of tourists. For example, the findings suggest the need to offer a holistic experience of the region for some segments by pairing wine and food experiences. To this end, co-branding 
initiatives between wineries and local food companies can make a region more attractive to both tourists and wine tourists.

From a destination marketing perspective, the findings highlight the sensitivity of different groups to different attributes of the region. For example, some visitors (destination image CL3) are more sensitive to the availability of information about the region than others. This is particularly important for those who have not visited the region before. As the findings indicate, for some tourists (Wine Enthusiasts), the value-for-money and availability of other local products are important image associations to create a positive image of the region despite being primarily driven by the motive of tasting wine on their visit. This pinpoints to the type of destination attributes that must be emphasized in communication strategies to attract specific segments. However, it must be noted that the majority of visitors belong to the Wine Buyers cluster, which in itself suggests that marketing efforts of the region must still emphasize the quality of the wines and uniqueness of the region in comparis on to other wine regions in Australia. Destination marketers should also look at ways of building local support for the tourism industry given that the destination attribute "friendly local residents" was not associated with the region by a considerable proportion of visitors (Destination image - CL1).

From a methodological perspective, while several wine tourism segmentation studies (Chen \& Sasias, 2014; Cho et al., 2017; Nella \& Christou, 2014) continue to use the muchcriticized factor-cluster analysis (Dolnicar \& Grün, 2008) to derive segments, this study offers a novel method to segment markets. Using well-established criteria of robustness and stability, which are important markers for identifying segments that are reproducible, we provide a stepby-step analytical framework that can be applied to other segmentation studies within and outside the field of tourism. The study extends the growing literature on relatively newer methods for segmenting markets by offering an ensemble method that is based on two segmentation methods, BC (Dolnicar \& Leisch, 2003; Prayag et al., 2015) and SOM (Brida et al., 2012; Mazanec, 1994) that have been applied separately in tourism studies.

In summary, the study offered both theoretical and managerial implications for understanding the tourist experience at the cellar door. However, it is not without limitations. First, the results are not generalizable beyond tourists to the region. Second, while the measured motivations reflect mainly those of wine tourists, it is possible that other motives that have not been captured by the study such as novelty and escape might also play a role in cellar door visits. Third, the destination image attributes measured reflect only cognitive images of the 
destination. As such, these limitations open several avenues for further research. Future studies can assess a broader set of motives that encapsulate both those pertinent to wine tourists but also the general motives of holidaymakers. While destination image remains a topical area of research within the tourism literature, the evolution of the image of wine tourism regions (i.e. Barossa) and the corresponding effects on the broader regional destination image (South Australia) should be investigated. Likewise, the dynamics between the cognitive and affective images of wineries and how they impact the wine region image remains to be assessed.

\section{REFERENCES}

Alant, K., \& Bruwer, J. (2004). Wine tourism behaviour in the context of a motivational framework for wine regions and cellar doors. Journal of Wine Research, 15(1), 27-37.

Albayrak, T., \& Caber, M. (2013). The symmetric and asymmetric influences of destination attributes on overall visitor satisfaction. Current Issues in Tourism, 16(2), 149-166.

Alebaki, M. \& Iakovidou, O. (2011). Market segmentation in wine tourism: A comparison of approaches. Tourismos: An International Multidisciplinary Journal of Tourism, 6(1), 123-140.

Andersson, T.D. (2007). The tourist in the experience economy. Scandinavian Journal of Hospitality and Tourism, 7(1), 46-58.

Asero, V., \& Patti, S. (2011). Wine tourism experience and consumer behaviour: The case of Sicily. Tourism Analysis: An Interdisciplinary Journal, 16(4), 431-442.

Baloglu, S., \& Uysal, M. (1996). Market segments of push and pull motivations: A canonical correlation approach. International Journal of Contemporary Hospitality Management, 8(3), 32-38.

Brida, J.G., Disegna, M., \& Osti, L. (2012). Segmenting visitors of cultural events by motivation: A sequential non-linear clustering analysis of Italian Christmas Market visitors. Expert Systems with Applications, 39(13), 11349-11356.

Bruwer, J., \& Alant, K. (2009). The hedonic nature of wine tourism consumption: An experiential view. International Journal of Wine Business Research, 21(3), 235-257. 
Bruwer. J., Coode, M., Saliba, A.J., \& Herbst, F. (2013). Wine experience effects of the tasting room on consumer brand loyalty. Tourism Analysis: An Interdisciplinary Journal, 8(4), $339-414$.

Bruwer, J., \& Gross, M.J. (2017). A multilayered macro approach to conceptualizing the winescape construct for wine tourism. Tourism Analysis: An Interdisciplinary Journal, 23(4), 497-509.

Bruwer, J., Gross, M.J., \& Lee, H.C. (2016). Tourism destination image (TDI) perception within a regional winescape context. Tourism Analysis: An Interdisciplinary Journal, 21(2-3), 173-187.

Bruwer, J., \& Joy, A. (2017). Tourism destination image (TDI) perception of a Canadian regional winescape: A free-text macro approach. Tourism Recreation Research, 42(3), 367-379.

Bruwer, J., Lesschaeve, I., \& Campbell, B.L. (2012). Consumption dynamics and demographics of Canadian wine consumers: Retailing insights from the tasting room channel, Journal of Retailing and Consumer Services, 19(1), 45-58.

Charters, S., \& Ali-Knight, J. (2002). Who is the wine tourist? Tourism Management, 23(1), 311-319.

Chen, X., Bruwer, J., Cohen, J., \& Goodman, S. (2016). A wine tourist behaviour model for Australian winery cellar doors. Tourism Analysis: An Interdisciplinary Journal, 21(1), 77-91.

Chen, L.J., \& Chen, W.P. (2015). Push-pull factors in international birders' travel. Tourism Management, 48, 416-425.

Chen, H.J., \& Sasias, M. (2014). Tourist segmentation in Taiwan's wineries: A cultural perspective. Social Behavior and Personality: An International Journal, 42(2), 223-236.

Cho, M., Bonn, M.A., \& Brymer, R.A. (2017). A constraint-based approach to wine tourism market segmentation. Journal of Hospitality and Tourism Research, 41(4), 415-444.

Correia, A., \& Pimpão, A. (2008). Decision-making process of Portuguese tourists travelling to South America and Africa. International Journal of Culture, Tourism and Hospitality Research, 2(4), 330-373. 
Dann, G.M. (1977). Anomie, ego-enhancement and tourism. Annals of Tourism Research, 4(4), 184-194.

Dolnicar, S., \& Grün, B. (2008). Challenging “factor-cluster segmentation”. Journal of Travel Research, 47(1), 63-71.

Dolnicar, S., \& Leisch, F. (2003). Winter tourist segments in Austria: Identifying stable vacation styles using bagged clustering techniques. Journal of Travel Research, 41(3), 281-292.

Dolnicar, S., \& Leisch, F. (2004). Segmenting markets by bagged clustering. Australasian Marketing Journal, 12(1), 51-65.

Dolnicar, S., Kaiser, S., Lazarevski, K., \& Leisch, F. (2012). Biclustering: overcoming data dimensionality problems in market segmentation. Journal of Travel Research,51(1), 41-49.

Douglas, N., Douglas, N., \& Derrett, R. (2001). Special interest tourism: Context and cases, John Wiley \& Sons: Sydney, Australia.

D’Urso, P., Disegna, M., Massari, R., \& Prayag, G. (2015). Bagged fuzzy clustering for fuzzy data: An application to a tourism market. Knowledge-Based Systems, 73, 335-346.

Everitt, B.S., Landau, S., Leese, M., \& Stahl, D. (2011). Cluster Analysis. (Fifth ed.). Wiley series in probability and statistics, John Wiley \& Sons, Ltd.

Getz, D., \& Brown, G. (2006). Critical success factors for wine tourism regions: A demand analysis. Tourism Management, 27(1), 146-158.

Hirschman, E.C. \& Holbrook, M.B. (1982). Hedonic consumption: Emerging concepts, methods and propositions. Journal of Marketing, 46(3), 92-101.

Hsu, C.H.C., Cai, L.A., \& Li, M. (2010). Expectation, motivation, and attitude: A tourist behavioral model. Journal of Travel Research, 49(3), 282-296.

Kim, S-H., Holland, S., \& Han, H-S. (2013). A structural model for examining how destination image, perceived value, and service quality affect destination loyalty: A case study of Orlando. International Journal of Tourism Research, 15(4), 313-328. 
Kim, S.S., Lee, C.K., \& Klenosky, D.B. (2003). The influence of push and pull factors at Korean national parks. Tourism Management, 24(2), 169-180.

Klenosky, D.B. (2002). The "pull" of tourism destinations: A means-end investigation. Journal of Travel Research, 40(4), 396-403.

Knutson, B.J., Beck, J.A., Kim, S.H. \& Cha, J. (2007). Identifying the dimensions of the experience construct. Journal of Hospitality and Leisure Marketing, 15(3), 31-47.

Kohonen, T. (1984). Self-organizing and associative memory (3rd ed. 1989). Berlin, Heidelberg, Germany: Springer-Verlag.

Kohonen, T. (1995). Self-Organizing Maps. Springer Series in Information Sciences 30. Berlin, Heidelberg, New York: Springer.

Kohonen, T. (1998). The self-organizing map. Neurocomputing, 20, 1-6.

Li, G., Law, R., \& Wang, J. (2010). Analyzing international travelers' profile with selforganizing maps. Journal of Travel and Tourism Marketing, 27(2), 113-131.

Li, X. R., Meng, F., Uysal, M., \& Mihalik, B. (2013). Understanding China's long-haul outbound travel market: An overlapped segmentation approach. Journal of Business Research, 66(6), 786-793.

Marzo-Navarro, M., \& Pedraja-Iglesias, M. (2012). Critical factors of Wine Tourism: Incentives and Barriers from the Potential Tourist's Perspective. International Journal of Contemporary Hospitality Management, 24(2), 312-334.

Mazanec, J.A. (1994). Image measurement with self-organizing maps: A tentative application to Austrian tour operators. The Tourist Review, 49(3), 9-18.

Mitchell, R. \& Hall, C.M. (2006). Wine tourism research: the state of play. Tourism Review International, 9(4), 307-332.

Mohsin, A., \& Alsawafi, A.M. (2011). Exploring attitudes of Omani students towards vacations. Anatolia: An International Journal of Tourism and Hospitality Research, 22(1), $35-46$. 
Molina, A., Gómez, M., González-Díaz, B., \& Esteban, Á. (2015). Market segmentation in wine tourism: Strategies for wineries and destinations in Spain. Journal of Wine Research, 26(3), 192-224.

Nella, A., \& Christou, E. (2014). Segmenting wine tourists on the basis of involvement with wine. Journal of Travel \& Tourism Marketing, 31(7), 783-798.

Nicolau, J.L., \& Mas, F.J. (2006). The influence of distance and prices on the choice of tourist destinations: The moderating role of motivations. Tourism Management, 27(5), 982-996.

Opitz, D., \& Maclin, R. (1999). Popular ensemble methods: An empirical study. Journal of Artificial Intelligence Research, 11, 169-198.

Pearce, P. L., \& Lee, U- I. (2005). Developing the travel career approach to tourism motivation. Journal of Travel Research, 43(3), 226-237.

Pikkemaat, B., Peters, M., Boksberger, P., \& Secco, M. (2009). The staging of experiences in wine tourism. Journal of Hospitality Marketing and Management, 18(2-3), 237-253.

Pine, B.J., \& Gilmore, J.H. (1998). Welcome to the experience economy. Harvard Business Review, 76(4), 97-105.

Prayag, G. (2010). Images as pull factors of a tourist destination: A factor-cluster segmentation analysis. Tourism Analysis: An Interdisciplinary Journal, 15(2), 213-226.

Prayag, G., Disegna, M., Cohen, S.A., \& Yan, H. (2015). Segmenting markets by bagged clustering: Young Chinese travelers to Western Europe. Journal of Travel Research, 54(2), 234-250.

Prayag, G., \& Hosany, S. (2014). When Middle East meets West: Understanding the motives and perceptions of young tourists from United Arab Emirates. Tourism Management, $40,35-45$.

Prayag, G., \& Ryan, C. (2011). The relationship between the 'push' and 'pull' factors of a tourist destination: The role of nationality - an analytical qualitative research approach. Current Issues in Tourism, 14(2), 121-143.

Quadri-Felitti, D., \& Fiore, A.M. (2012). Experience economy constructs as a framework for understanding wine tourism. Journal of Vacation Marketing, 18(1), 3-15. 
Quintal, V.A., Thomas, B., \& Phau, I. (2015). Incorporating the winescape into the theory of planned behaviour: Examining 'New World' wineries. Tourism Management, 46, 596-609.

Ravenscroft, N., \& van Westering, J. (2001). Wine tourism, culture and the everyday: A theoretical note. Tourism and Hospitality Research, 3(2), 49-162.

Romano, M.F., \& Natilli, M. (2009). Wine tourism in Italy: New profiles, styles of consumption, ways of touring. Tourism: An International Interdisciplinary Journal, 57(4), 463-475.

Sang, H., Gelfand, A.E., Lennard, C., Hegerl, G., \& Hewitson, B. (2008). Interpreting selforganizing maps through space-time data models. The Annals of Applied Statistics, 2(4), 1194-1216.

Sparks, B. (2007). Planning a wine tourist vacation? Factors that help to predict tourist behavioural intentions. Tourism Management, 28(5), 1180-1192.

Stepchenkova, S., \& Mills, J.E. (2010). Destination image: A meta-analysis of 2000-2007 research. Journal of Hospitality Marketing and Management, 19(6), 575-609.

Venugopal, V., \& Baets, W. (1994). Neural networks and statistical techniques in marketing research: A conceptual comparison. Marketing Intelligence and Planning, 12(7), 30-38.

Vesanto, J., \& Alhoniemi, E. (2000). Clustering of the self-organizing map. IEEE Transactions on Neural Networks, 11(3), 586-600.

Yuan, J., Cai, L.A., Morrison, A.M., \& Linton, S. (2005). An analysis of wine festival attendees' motivations: A synergy of wine, travel and special events? Journal of Vacation Marketing, 11(1), 41-58. 
Figure 1: Stages of the segmentation process

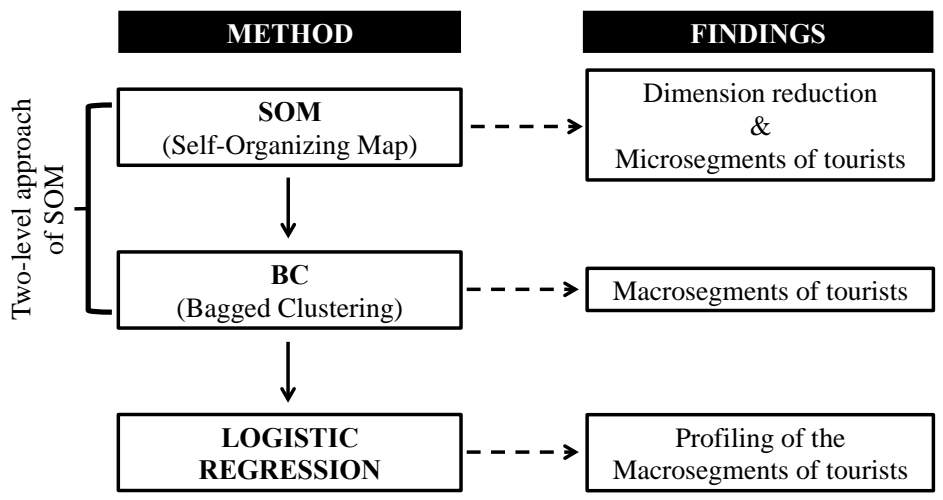

Figure 2: $U$-matrix for the SOM algorithm

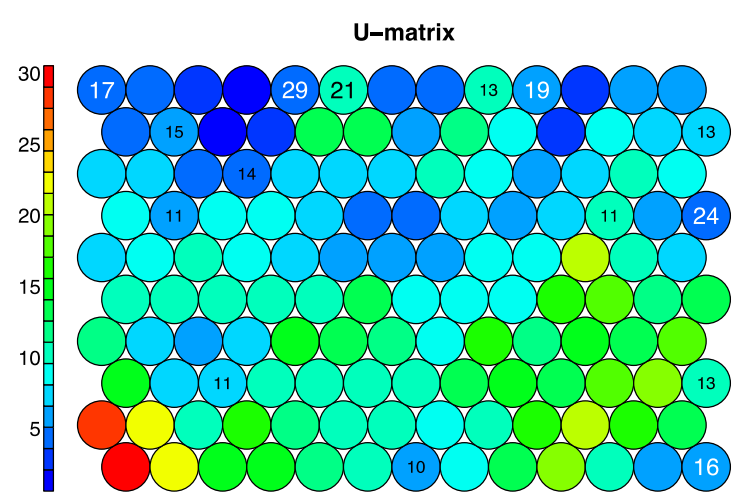


Figure 3: Dendrogram and plot of relative height of aggregation (black line) and first differences (grey line)

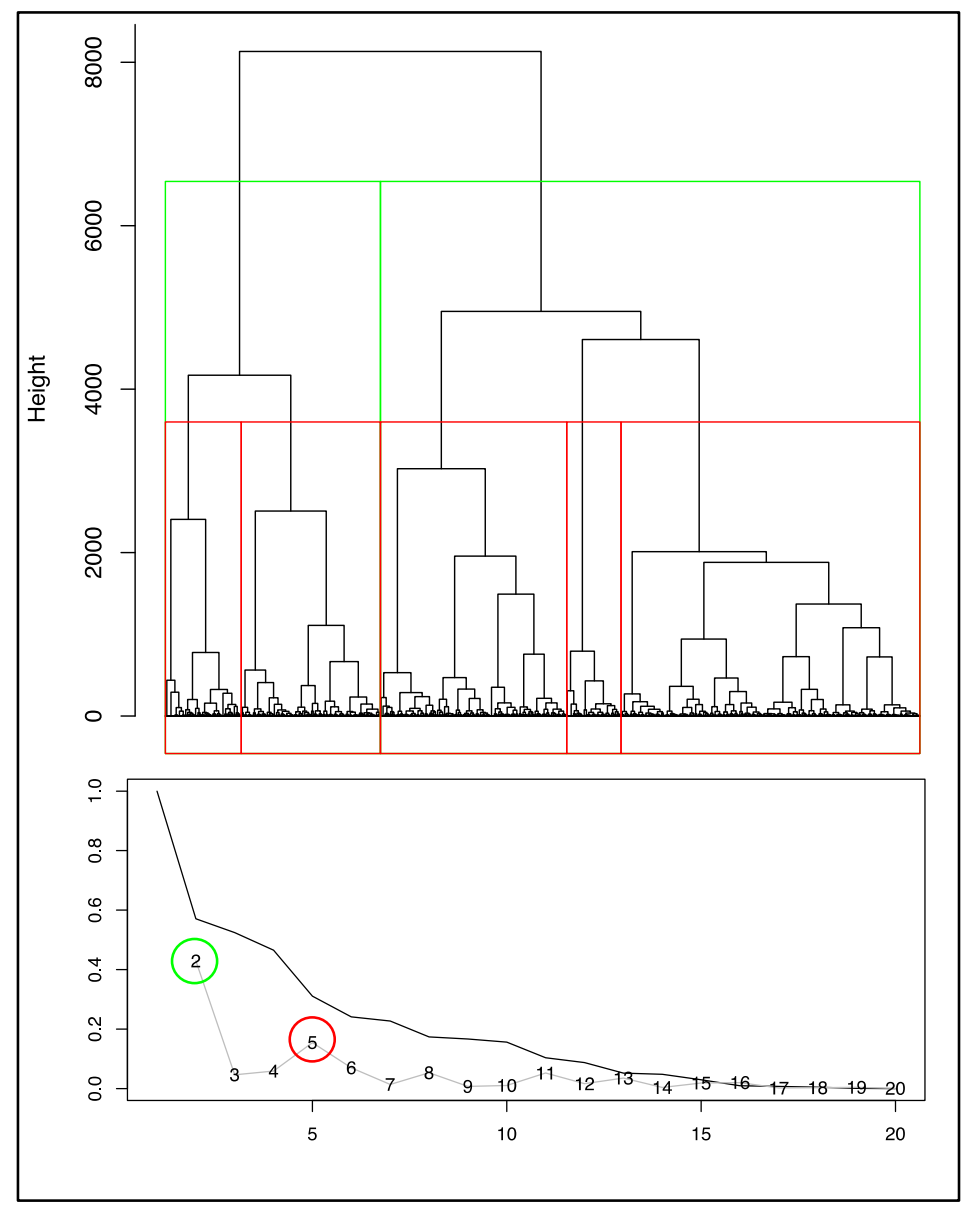


Table 1: Motivation Clusters

\begin{tabular}{|c|c|c|c|c|c|c|c|c|c|c|}
\hline $\begin{array}{l}\text { No. of } \\
\text { observations }\end{array}$ & $\mathrm{n}=48$ & $7 \%$ & $n=141$ & $21 \%$ & $n=332$ & $49 \%$ & $n=27$ & $4 \%$ & $n=128$ & $19 \%$ \\
\hline RANK & CL 1 (Wine Learners) & & CL 2 (Dining Enthusiasts) & & CL 3 (Wine Buyers) & & CL 4 (Wine Enthusiasts) & & CL 5 (Wine Connoisseurs) & \\
\hline 1 & Taste wine & $52 \%$ & Eat at winery & $25 \%$ & Taste wine & $61 \%$ & Taste wine & $33 \%$ & Taste wine & $47 \%$ \\
\hline 2 & $\begin{array}{l}\text { Atmosphere, Buy wine, } \\
\text { Day out }\end{array}$ & $21 \%$ & Atmosphere & $13 \%$ & Buy wine & $26 \%$ & Taste wine & $37 \%$ & Taste wine & $20 \%$ \\
\hline 3 & Learn about wine & $23 \%$ & Atmosphere & $13 \%$ & Buy wine & $12 \%$ & Learn about wine & $19 \%$ & Taste wine & $13 \%$ \\
\hline 4 & $\begin{array}{l}\text { Learn about wine, } \\
\text { Information, Unique wine }\end{array}$ & $10 \%$ & Rural setting & $7 \%$ & Buy wine & $10 \%$ & Day out & $19 \%$ & Buy wine & $16 \%$ \\
\hline 5 & Atmosphere & $23 \%$ & Entertainment & $6 \%$ & $\begin{array}{l}\text { Atmosphere, Unique } \\
\text { wine }\end{array}$ & $5 \%$ & Winery tour & $30 \%$ & Buy wine, Unique wine & $12 \%$ \\
\hline 6 & Picnic/BBQ & $17 \%$ & Learn about wine & $4 \%$ & Unique wine & $2 \%$ & Unique wine & $7 \%$ & Atmosphere & $15 \%$ \\
\hline 7 & Entertainment & $10 \%$ & Unique wine & $3 \%$ & Day out & $1 \%$ & $\begin{array}{l}\text { Taste wine, Buy } \\
\text { merchandise, Winery tour }\end{array}$ & $4 \%$ & Day out & $12 \%$ \\
\hline 8 & Information & $15 \%$ & $\begin{array}{l}\text { Learn about wine, Rural setting, } \\
\text { Buy merchandise, Socialise }\end{array}$ & $1 \%$ & $\begin{array}{l}\text { Learn about wine, Buy } \\
\text { merchandise }\end{array}$ & $0 \%$ & Day out & $7 \%$ & Day out & $12 \%$ \\
\hline 9 & Picnic/BBQ & $19 \%$ & $\begin{array}{l}\text { Rural setting, Buy wine, Unique } \\
\text { wine }\end{array}$ & $1 \%$ & Unique wine & $1 \%$ & & & Information & $8 \%$ \\
\hline 10 & Meet winemaker & $17 \%$ & Unique wine & $2 \%$ & Rural setting & $0 \%$ & & & $\begin{array}{l}\text { Entertainment, Meet } \\
\text { winemaker }\end{array}$ & $7 \%$ \\
\hline 11 & Unique wine & $10 \%$ & Buy merchandise & $3 \%$ & & & & & Socialise & $9 \%$ \\
\hline 12 & Socialise & $10 \%$ & Entertainment, Meet winemaker & $1 \%$ & & & & & Picnic/BBQ & $8 \%$ \\
\hline 13 & Socialise & $13 \%$ & Information, Unique wine & $1 \%$ & & & & & Picnic/BBQ & $11 \%$ \\
\hline 14 & Eat at winery & $13 \%$ & Winery tour & $1 \%$ & & & & & Picnic/BBQ & $12 \%$ \\
\hline 15 & Eat at winery & $63 \%$ & Picnic/BBQ & $100 \%$ & $\begin{array}{l}\text { Picnic/BBQ, Meet } \\
\text { winemaker, Winery tour }\end{array}$ & $100 \%$ & Picnic/BBQ, Meet winemaker & $100 \%$ & Picnic/BBQ & $62 \%$ \\
\hline
\end{tabular}


Table 2: Destination image clusters

\begin{tabular}{|c|c|c|c|c|c|c|c|c|c|}
\hline \multirow{3}{*}{ Destination image attributes } & \multirow{3}{*}{ Items } & \multicolumn{5}{|c|}{ Proportion of Yes } & \multicolumn{3}{|c|}{ Significance } \\
\hline & & \multirow{2}{*}{$\begin{array}{l}\text { Sample } \\
(n=671)\end{array}$} & \multirow{2}{*}{$\begin{array}{c}\text { CL1 } \\
(n=200)\end{array}$} & \multirow{2}{*}{$\begin{array}{c}\text { CL2 } \\
(n=357)\end{array}$} & \multirow{2}{*}{$\begin{array}{c}\text { CL3 } \\
(n=114)\end{array}$} & \multirow[t]{2}{*}{ ANOVA } & \multicolumn{3}{|c|}{ Tukey's pairwise comparison } \\
\hline & & & & & & & $\mathrm{cl} 1-\mathrm{cl} 2$ & cl1-cl3 & $\mathrm{cl} 2-\mathrm{cl} 3$ \\
\hline Local food/cuisine & 1 & $73.17 \%$ & $72.50 \%$ & $76.75 \%$ & $63.16 \%$ & $*$ & & & $*$ \\
\hline Quality of the restaurants / pubs & 2 & $88.67 \%$ & $94.00 \%$ & $84.59 \%$ & $92.11 \%$ & $* *$ & $* *$ & & \\
\hline Availability of tourist information & 3 & $60.66 \%$ & $55.50 \%$ & $56.58 \%$ & $82.46 \%$ & $* * *$ & & $* * *$ & $* * *$ \\
\hline Local transportation & 4 & $19.52 \%$ & $17.00 \%$ & $22.13 \%$ & $15.79 \%$ & & & & \\
\hline Heritage and cultural attractions & 5 & $54.25 \%$ & $54.50 \%$ & $51.26 \%$ & $63.16 \%$ & & & & \\
\hline Scenery, natural environment & 6 & $59.31 \%$ & $64.00 \%$ & $57.14 \%$ & $57.89 \%$ & & & & \\
\hline Reputation & 7 & $20.42 \%$ & $18.50 \%$ & $19.89 \%$ & $25.44 \%$ & & & & \\
\hline Value-for-money & 8 & $30.25 \%$ & $29.00 \%$ & $27.73 \%$ & $40.35 \%$ & $*$ & & & $*$ \\
\hline Vineyard landscape & 9 & $6.71 \%$ & $5.50 \%$ & $6.72 \%$ & $8.77 \%$ & & & & \\
\hline Friendly local residents & 10 & $1.94 \%$ & $0.00 \%$ & $3.36 \%$ & $0.88 \%$ & $*$ & $*$ & & \\
\hline Safety and security & 11 & $16.84 \%$ & $16.00 \%$ & $17.37 \%$ & $16.67 \%$ & & & & \\
\hline Signage to get to and move through the region & 12 & $19.97 \%$ & $13.00 \%$ & $26.33 \%$ & $12.28 \%$ & $* * *$ & $* * *$ & & $* *$ \\
\hline Leisure time facilities / activities & 13 & $15.50 \%$ & $17.50 \%$ & $15.97 \%$ & $10.53 \%$ & & & & \\
\hline Accommodation offered (hotels, B\&Bs, apartments) & 14 & $14.01 \%$ & $14.50 \%$ & $12.89 \%$ & $16.67 \%$ & & & & \\
\hline Nightlife and entertainment & 15 & $33.68 \%$ & $29.50 \%$ & $36.97 \%$ & $30.70 \%$ & & & & \\
\hline Lack of urbanization & 16 & $22.80 \%$ & $24.00 \%$ & $23.53 \%$ & $18.42 \%$ & & & & \\
\hline Atmosphere / climate / ambience & 17 & $4.47 \%$ & $1.00 \%$ & $7.84 \%$ & $0.00 \%$ & $* * *$ & $* * *$ & & $* * *$ \\
\hline Shopping facilities & 18 & $31.89 \%$ & $31.50 \%$ & $35.57 \%$ & $21.05 \%$ & $*$ & & & $* *$ \\
\hline Other local products / cottage industries & 19 & $32.19 \%$ & $34.50 \%$ & $27.73 \%$ & $42.11 \%$ & $*$ & & & $*$ \\
\hline Wines & 20 & $31.00 \%$ & $25.50 \%$ & $32.49 \%$ & $35.96 \%$ & & & & \\
\hline Proximity of the region to a main city & 21 & $12.22 \%$ & $2.00 \%$ & $19.33 \%$ & $7.89 \%$ & $* * *$ & $* * *$ & & $* *$ \\
\hline Towns / villages & 22 & $50.37 \%$ & $51.00 \%$ & $51.26 \%$ & $46.49 \%$ & & & & \\
\hline Cleanliness & 23 & $16.39 \%$ & $11.50 \%$ & $19.61 \%$ & $14.91 \%$ & $*$ & $*$ & & \\
\hline Natural settings of the wineries & 24 & $22.80 \%$ & $27.00 \%$ & $22.97 \%$ & $14.91 \%$ & $*$ & & $*$ & \\
\hline
\end{tabular}

Note: $* * *$ Significant at $\mathrm{p} \leq 0.001,{ }^{* *}$ significant at $\mathrm{p} \leq 0.01, *$ significant at $\mathrm{p} \leq 0.05$ 
Table 3: Profiling of clusters by image and socio-demographic characteristics

\begin{tabular}{|c|c|c|c|c|c|c|c|c|}
\hline \multirow[b]{3}{*}{ Destination Image Clusters } & \multicolumn{6}{|c|}{ Motivation Clusters } & \multirow[b]{2}{*}{$p$-value } & \multirow[b]{2}{*}{ Significance } \\
\hline & CL1 (\%) & CL2 (\%) & CL3 (\%) & CL4 (\%) & CL5 (\%) & Sample (\%) & & \\
\hline & & & & & & & 0.485 & \\
\hline CL1 & 35.42 & 33.09 & 30.00 & 11.11 & 27.56 & 29.81 & & \\
\hline $\mathrm{CL2}$ & 45.83 & 52.52 & 52.12 & 70.37 & 55.91 & 53.20 & & \\
\hline CL3 & 18.75 & 14.39 & 17.88 & 18.52 & 16.54 & 16.99 & & \\
\hline Visitation status to the wine region (first-time vs repeat) & 31.25 & 53.90 & 47.29 & 40.74 & 54.69 & 48.67 & 0.038 & * \\
\hline Average number of previous visits & 2.167 & 3.617 & 3.428 & 2.333 & 3.578 & 3.362 & 0.495 & \\
\hline Main purpose of visit to the wine region & & & & & & & 0.205 & \\
\hline Wine tourism & 39.58 & 43.26 & 44.28 & 55.56 & 50 & 45.27 & & \\
\hline Holiday & 50 & 33.33 & 33.43 & 25.93 & 34.38 & 34.47 & & \\
\hline Other purpose & 10.42 & 23.4 & 22.29 & 18.52 & 15.62 & 20.27 & & \\
\hline Previous visit to Winery's cellar door & 77.08 & 78.01 & 71.39 & 74.07 & 65.62 & 72.19 & 0.210 & \\
\hline Average number of times visited the Winery's cellar door in the past & 1.521 & 1.574 & 1.804 & 1.481 & 1.867 & 1.735 & 0.397 & \\
\hline You heard of this Winery before today & 70.83 & 78.72 & 78.92 & 74.07 & 74.22 & 77.22 & 0.619 & \\
\hline You bought any of this winery's wine(s) at retail stores or elsewhere in the last 2 months & 20.83 & 19.15 & 25.6 & 25.93 & 25.98 & 24.00 & 0.578 & \\
\hline You tasted wine at this winery's cellar door today & 91.49 & 87.23 & 87.77 & 100.00 & 87.1 & 88.29 & 0.348 & \\
\hline Average number of different wines tasted & 5.191 & 5.071 & 4.819 & 4.741 & 4.894 & 4.910 & 0.893 & \\
\hline Any purchase(s) at this winery's cellar door today & 54.17 & 62.14 & 59.76 & 59.26 & 64.29 & 60.69 & 0.771 & \\
\hline Average number of bottles bought & 2.917 & 3.823 & 2.630 & 2.296 & 2.906 & 2.938 & 0.409 & \\
\hline Average amount spent on wine alone & 55.729 & 92.485 & 64.112 & 47.726 & 74.293 & 70.708 & 0.297 & \\
\hline Average amount spent at this winery's cellar door on food and merchandise & 15.104 & 10.411 & 6.108 & 5.3704 & 5.234 & 7.450 & 0.166 & \\
\hline Average total amount spent at this winery's cellar door & 70.833 & 102.896 & 70.220 & 53.096 & 79.527 & 78.158 & 0.240 & \\
\hline Wine consumption frequency & & & & & & & 0.870 & \\
\hline Once a day & 16.67 & 19.15 & 15.66 & 11.11 & 12.5 & 15.68 & & \\
\hline A few times a week & 56.25 & 51.06 & 51.51 & 51.85 & 54.69 & 52.37 & & \\
\hline Once a week & 12.5 & 10.64 & 12.05 & 22.22 & 10.94 & 11.98 & & \\
\hline Less than once a week & 14.58 & 19.15 & 20.78 & 14.81 & 21.88 & 19.97 & & \\
\hline Average amount spent as a household on wine in total in a typical month & 127.604 & 143.901 & 125.889 & 152.593 & 134.648 & 132.49 & 0.522 & \\
\hline \multicolumn{9}{|l|}{ Socio-demographic and economic variables } \\
\hline Male & 66.67 & 69.50 & 43.67 & 48.15 & 53.12 & 52.66 & 0.000 & $* * *$ \\
\hline Age & & & & & & & 0.839 & \\
\hline $18-28$ years & 20.83 & 20.57 & 19.58 & 14.81 & 28.91 & 21.45 & & \\
\hline $29-40$ years & 25.00 & 32.62 & 31.63 & 33.33 & 28.91 & 30.92 & & \\
\hline $41-54$ years & 31.25 & 28.37 & 28.31 & 33.33 & 25.78 & 28.25 & & \\
\hline 55 years and older & 22.92 & 18.44 & 20.48 & 18.52 & 16.41 & 19.38 & & \\
\hline Level of education & & & & & & & 0.069 & \\
\hline School Leaving Certificate (15 yrs+), HSC & 22.92 & 26.95 & 22.66 & 11.11 & 11.81 & 21.07 & & \\
\hline TAFE certificate/diploma & 12.50 & 17.02 & 16.01 & 14.81 & 22.83 & 17.21 & & \\
\hline Bachelor's degree & 25.00 & 30.50 & 26.59 & 51.85 & 33.07 & 29.53 & & \\
\hline Graduate/Postgraduate diploma & 25.00 & 15.60 & 20.85 & 11.11 & 22.83 & 20.03 & & \\
\hline Masters/Doctorate degree & 14.58 & 9.93 & 13.90 & 11.11 & 9.45 & 12.17 & & \\
\hline
\end{tabular}




\begin{tabular}{|c|c|c|c|c|c|c|c|}
\hline State of origin & & & & & & & 0.410 \\
\hline Australia & 75.00 & 83.69 & 84.64 & 74.07 & 89.06 & 84.17 & \\
\hline EU & 14.58 & 7.80 & 8.73 & 14.81 & 5.47 & 8.58 & \\
\hline Other countries & 10.42 & 8.51 & 6.63 & 11.11 & 5.47 & 7.25 & \\
\hline Household's approximate total annual income (before taxes) & & & & & & & 0.593 \\
\hline less than $\$ 50,000$ & 4.17 & 10.64 & 15.66 & 18.52 & 12.50 & 13.31 & \\
\hline$\$ 50,001$ to $\$ 75,000$ & 18.75 & 19.86 & 18.07 & 7.41 & 13.28 & 17.16 & \\
\hline$\$ 75,001$ to $\$ 100,000$ & 20.83 & 18.44 & 16.87 & 25.93 & 23.44 & 19.08 & \\
\hline$\$ 100,001$ to $\$ 150,000$ & 18.75 & 23.40 & 20.18 & 22.22 & 21.09 & 21.01 & \\
\hline$\$ 150,000$ plus & 37.50 & 27.66 & 29.22 & 25.93 & 29.69 & 29.44 & \\
\hline
\end{tabular}

Note: Significance of both the Chi-square test (for qualitative data) and the repeated measures ANOVA (for quantitative data) are reported. Test results are not significant unless indicated otherwise: **Significant at $p \leq 0.05,{ }^{*}$ Significant at $p \leq 0.1$ 
Table 4: Multinomial logit stepwise estimations

\begin{tabular}{|c|c|c|c|c|}
\hline \multirow[b]{2}{*}{ Independent variables } & \multicolumn{4}{|c|}{ Motivation Clusters } \\
\hline & CL1 & CL2 & CL3 & CL5 \\
\hline Q6_cl2 & $-1.503(0.71)^{* *}$ & $-1.403(0.65)^{* *}$ & $-1.311(0.64)^{* *}$ & $-1.158(0.66)^{*}$ \\
\hline Q6_cl3 & $-1.137(0.86)$ & $-1.378(0.80)^{*}$ & $-1.029(0.77)$ & $-1.005(0.80)$ \\
\hline $\begin{array}{l}\text { How much in total did you } \\
\text { here on wine alone? }\end{array}$ & $0.001(>0.01)$ & $0.002(>0.01)^{*}$ & $0.001(>0.01)$ & $0.001(>0.01)$ \\
\hline Male & $0.776(0.49)$ & $1.02(0.43)^{* *}$ & $-0.111(0.40)$ & $0.288(0.42)$ \\
\hline State of origin: EU & $-0.325(0.70)$ & $-0.884(0.66)$ & $-0.668(0.59)$ & $-1.204(0.68)^{*}$ \\
\hline \multicolumn{5}{|c|}{ Household's approximate total annual income (before taxes) category } \\
\hline$\$ 50,001$ to $\$ 75,000$ & $2.291(1.14)^{* *}$ & $1.441(0.88)$ & $0.975(0.85)$ & $0.904(0.90)$ \\
\hline$\$ 75,001$ to $\$ 100,000$ & $1.113(0.98)$ & $-0.031(0.67)$ & $-0.375(0.62)$ & $0.177(0.67)$ \\
\hline$\$ 100,001$ to $\$ 150,000$ & $1.311(1.00)$ & $0.53(0.71)$ & $0.103(0.65)$ & $0.359(0.70)$ \\
\hline$\$ 150,000$ plus & $1.665(0.96)^{*}$ & $0.355(0.69)$ & $0.195(0.63)$ & $0.401(0.68)$ \\
\hline Constant & $-0.106(1.01)$ & $1.681(0.73)^{* *}$ & $3.461(0.67)^{* * *}$ & $2.031(0.72)^{* * *}$ \\
\hline
\end{tabular}

Note: Test results are not significant unless indicated otherwise: ${ }^{* * *}$ Significant at $p \leq 0.01,{ }^{* *}$ Significant at $p \leq 0.05,{ }^{*}$ Significant at $p \leq 0.1$. Robust standard errors are in parentheses. $N=661$; Wald $\chi^{2}(36)=61.60 ; p>\chi 2=0.0050$; pseudo $-R^{2}=.0418$; McFadden $\mathrm{R}^{2}=.037$ 